\title{
Når kronisk syke barn blir voksne
}

Mange kroniske sykdommer hos barn har mye bedre prognose $i$ våre dager enn for noen tiår siden. Dermed vil langt flere syke barn nå voksen alder - noe som gir voksenmedisinen nye utfordringer. I dette nummer av Tidsskriftet drøfter Eva Albretsen Malt og medarbeidere de komplekse helseproblemene hos voksne med Downs syndrom (1). Her er noen flere eksempler.

De fleste medfødte syndromer kjennetegnes av sammensatte helseproblemer. Velo-kardio-facialt syndrom (DiGeorges syndrom) har en insidens på ca. $1 / 4000$, og er dermed blant de hyppigste. Den underliggende årsaken er en delesjon i den lange armen av kromosom 22. Det er stor variasjon i det kliniske bildet; de vanlige problemene omfatter hjertemisdannelser, hypoparatyreoidisme, moderat immunsvikt og endringer i ansiktsskjelettet som gir bihule- og mellomøreproblemer (2). Mange har dessuten lett psykisk utviklingshemning, og det er økt risiko for schizofreni og stemningslidelser.

Overlevelsestallene for prematurt fødte barn øker stadig; samtidig øker også andelen med funksjonsheminger (3). Blant dem som overlever en fødsel i svangerskapsuke 25 eller tidligere (i Norge ca. 50 barn årlig), får om lag $25 \%$ alvorlig cerebral parese. Andre vanlige langtidsproblemer er forstyrret språkutvikling, nedsatt syn og hørsel, lærevansker og økt risiko for AD/HD.

Hypoplastisk venstre hjertesyndrom innebærer at venstre hjertehalvdel er funksjonsløs. Insidensen blant levende fødte er ca. 1/10 000, og inntil 1980-tallet døde samtlige i nyfødtperioden. Nå kan så mange som $70 \%$ regne med å bli voksne (4). Behandlingen innebærer flere hjertekirugiske inngrep der sluttresultatet er en forbindelse mellom høyre hjertehalvdel og aorta, samtidig som det systemvenøse blodet renner passivt gjennom lungene utenom hjertet (Fontan-sirkulasjon). Denne situasjonen er ikke problemfri. Langtidskomplikasjoner omfatter arytmier, vedvarende tap av plasmaproteiner til tarmen, levercirrhose, koagulasjonsavvik og nevropsykologiske utviklingsforstyrrelser.

I mars 2012 ble den nasjonale nyfødtscreeningen utvidet til å omfatte 23 medfødte sykdommer - flertallet skyldes genetisk betingede defekter i stoffskifteenzymer. Den samlede insidensen av sykdommene som fanges opp av screeningprogrammet er ca. 1/1 000. Hovedelementet $i$ behandlingen er ofte en spesialtilpasset diett. Pasientene er likevel utsatt for langtidskomplikasjoner; ved tyrosinemi er det for eksempel betydelig økt fare for levercirrhose og hepatocellulært karsinom, og en stor andel pasienter må etter hvert levertransplanteres (5).

Disse fire eksemplene illustrerer følgende generelle forhold: Stadig flere kronisk syke barn når voksen alder. Deres helsetilstand er svært sammensatt (mange organer og funksjoner er påvirket), samtidig som hvert enkelt helseproblem kan være både sjeldent og komplisert i seg selv.

Dette krever et helsetilbud som både er helhetlig og høyspesialisert. Personer med Downs syndrom trenger for eksempel en habiliteringstjeneste som tar hensyn til deres totale livssituasjon (1). Samtidig bør deres hjertefunksjon i mange tilfeller vurderes av kardiolog med spesialkompetanse i medfødte hjertefeil. Et slikt kombinert behov harmonerer dårlig med et dominerende utviklingstrekk i norsk medisin der den helhetlige tilnærmingen til pasienten blir stadig mer fraværende i spesialisthelsetjenesten. Først ble medisinen organoppdelt; nå er det organisatoriske prinsippet $\mathrm{i}$ ferd med å flyttes til delorgannivå, samtidig som «samlebåndsprinsippet» idealiseres (6). Men når kronisk syke barn blir voksne, trenger de både subspesialister og avanserte generalister, for øvrig i likhet med mange andre pasientgrupper, som akutt syke gamle (7).

Tilsvarende både-og-prinsipp gjelder for forskning, som generelt er en mangelvare. En nærmere forståelse av proteintap hos pasienter med Fontan-sirkulasjon forutsetter for eksempel bruk av avanserte metoder fra gastroenterologi, kardiologi og integrert organfysiologi. Forskning på medfødte stoffskiftesykdommer avhenger av et nært samarbeid mellom klinikere, biokjemikere og molekylærbiologer. Vitenskapelig erkjennelse innen dette feltet krever altså både høyspesialiserte teknikker og evne til integrasjon på tvers av tradisjonelle fagdisipliner. Det siste er sjelden godt ivaretatt.

Disse organisatoriske manglene blir spesielt tydelige i praksis når kronisk syke barn skal overføres fra pediatrisk til voksenmedisinsk omsorg. Generalistperspektivet er fremdeles levende i pediatrien, samtidig som foreldre/foresatte utgiør en integrert del av oppfølgingen. Ved 16-årsalderen blir pasientene brått utsatt for et langt mer fragmentert helsetilbud - ofte har de ikke lenger noen klar «adresse» - samtidig som de i større utstrekning forventes å ta ansvar for sin egen helsesituasjon. Noen protesterer på tenåringsvis mot denne situasjonen. Det kan få katastrofale følger, som når transplanterte pasienter plutselig nekter å ta immundempende legemidler (8).

Sykehusfagene må derfor ha ambisjoner om å kombinere det reduksjonistiske spesialistperspektivet med et avansert, helhetlig generalistperspektiv. Dette gjelder spesielt indremedisinen, som flertallet av disse pasientene naturlig vil sogne til. Organisatoriske omlegginger blir i så fall nødvendig, men det viktigste blir en holdningsendring. For i de fleste fagmiljøer er det mye «finere» å kunne mye om lite enn lite om mye. Det er derfor på høy tid å rehabilitere den generelle indremedisineren. Mange pasienter trenger ham/henne og det blir stadig flere av dem.

\section{Vegard Bruun Wyller}

brwylle@online.no

Vegard Bruun Wyller (f. 1972) er postdoktorstipendiat ved Kvinne- og Barneklinikken, Oslo universitetssykehus, Rikshospitalet og medisinsk redaktør i Tidsskriftet.

Forfatter har fylt ut ICMJE-skjemaet og oppgir ingen interessekonflikter.

\section{Litteratur}

1. Malt EA, Dahl RC, Haugsand TM et al. Helse og sykdom hos voksne med Downs syndrom. Tidsskr Nor Legeforen 2013; 133: $290-4$.

2. McDonald-McGinn DM, Sullivan KE. Chromosome 22q11.2 deletion syndrome (DiGeorge syndrome/velocardiofacial syndrome). Medicine (Baltimore) 2011; 90 $1-18$.

3. Milligan DW. Outcomes of children born very preterm i Europe. Arch Dis Child Neonatal Ed 2010; 95: F234-40

4. Feinstein JA, Benson DW, Dubin AM et al. Hypoplastic left heart syndrome: current considerations and expectations. J Am Coll Cardiol 2012; 59 (suppl): S1-42.

5. Bliksrud YT. Hereditary tyrosinemia type I. Studies on the molecular genetics and DNA repair enzymes. Ph.d.-gradsarbeid. Oslo: Det medisinske fakultet, Universitetet i Oslo, 2012.

6. Lundh F. Helse-Norge kan bli inspirert av Toyota. VG 21.1.2009. www.vg.no/ helse/artikkel. php?artid=536185 (7.1.2013).

Wyller TB. En døende spesialitet? Tidsskr Nor Legeforen 2012; 132: 1843.

8. Bell LE, Sawyer SM. Transition of care to adult services for pediatric solid-organ transplant recipients. Pediatr Clin North Am 2010; 57: 593-610. 